\title{
Populism, Media and Elections in Zambia: The case of the Patriotic Front in the 2011 and 2016 elections
}

\author{
${ }^{1}$ Basil N. Hamusokwe (D) \& ${ }^{*}$ Elastus Mambwe (iD) \\ ${ }^{1}$ Lecturer, University of Zambia, Lusaka, Zambia \\ ${ }^{2}$ Research Fellow, University of Zambia, Lusaka, Zambia
}

\begin{abstract}
This paper interrogates the intermingling of populist politics and the media in Zambia. It analyses populist tendencies the country's 2011 and 2016 presidential elections. The examination of the 2011 elections considers this coming together of populist Patriotic Front (PF) party figures and the media through the lens of The Post Newspaper, representing 'old' media. The 2016 elections examination focuses on alternative media, particularly looking at how the PF utilised popular music and social media, to communicate its populist ideas. The analysis shows that the PF, with and without their populist founder Michael Sata, managed to maintain close ties with the media for their political success. Later, they were willing to utilise and harness the potential of alternative media to meet their objectives in 2016. The paper however warns that the merging of media with populism is a danger that heavily compromises the ability of the media to serve the public as they should.
\end{abstract}

Keywords: populism; populist media; elections; Zambia; Michael Sata; Patriotic Front (PF)

\section{Article Publication}

Published Online: 15-Dec-2021

*Author's Correspondence

8 Elastus Mambwe

9 University of Zambia, Lusaka, Zambia

$\triangle$ elastus.mambwe@unza.zm

C 2021The Authors. Published by RESEARCH REVIEW International Journal of Multidisciplinary. This is an open access article under the CC BY-

NC-ND license CC

(https://creativecommons.org/licenses/ by-nc-nd/4.0/)

\section{Introduction}

The 2011 presidential elections in Zambia ushered into office the Patriot Front (PF), led by its charismatic founder, Michael Chilufya Sata. The PF, founded in 2001, had established itself as a party that would pursue propoor policies encapsulated in its slogan, 'for lower taxes and more money in your pocket.'

Through various studies, scholarship has established a populist turn in Zambian politics following the ascendance of Sata and the PF to prominence after the 2006 elections when it emerged as the largest opposition party (Larmer and Fraser, 2007; Cheeseman, Ford and Simutanyi, 2015; Fraser, 2017). By the run up to and after the subsequent elections in 2011, when the PF emerged victorious, populist politics had found a footing in Zambia and were entrenched in the media as well. In those elections, a bond or intermingling of the party and the private media, particularly The Post newspaper was observed. However, Sata's five-year term ended abruptly when he died in 2014. The Patriotic Front and its new presidential candidate, Edgar Chagwa Lungu, would still go on to win the constitutionally mandated by-election in 2015 to complete the first term, and later secure a new five-year mandate in 2016, following a highly contentious election.

Whilst still important, much of the scholarship on modern populism in Zambia has only focused on the rise of Michael Sata. However, such examination has often been done without comparison to another period outside the Sata-era. Questions on whether the populist turn was sustained in post-Sata Zambia remain unanswered. Studies linking populist politics and the media in Zambia are either limited or non-existent. Further, and perhaps more importantly for this paper, it is not known if and how the merger between populist politics and the media in Zambia has evolved. 
This paper discusses the intermingling of populist politics and the media in Zambia during and after the Michael Sata era. Specifically, it considers the 2011 and 2016 elections, comparing the Patriotic Front's appropriation of populist politics and the media during and after the Michael Chilufya Sata era. The paper does this in two layers. Firstly, it uses the 2011 elections to show the integration of populist politics with traditional media when the party was under Michael Chilufya Sata. Secondly, and using the 2016 general elections, the paper reviews the party's populist tendencies in the post-Sata era of the PF with a specific focus on the party's appropriation of alternative media, specifically, social media and popular music. The paper will attempt to determine whether the foothold of populism and populist media that gained prominence in the Sata years was maintained and if so, how it evolved. The paper first sets out to define populism within the context of democracy. It will then provide a brief historical and contextual sketch of the Zambian political landscape. Using various literature sources, it will highlight some examples of the populist turn and then go on to discuss populist politics and media in Zambia based on the two election periods. The paper will endeavour to show how the media have engaged with populism and how they have contributed to its sustained existence.

\section{Populism and Democracy}

The ambiguity and ambivalence of populism makes defining the concept difficult. Canovan (1999, p. 3) calls it "a notoriously vague term", while Laclau (1977, p. 143) describes it as an "elusive and recurrent" term often described with little precision as a result. Despite these challenges in defining the concept, several important elucidations provided have proved to be useful. Albertazzi and McDonnell (2008, p. 3) define populism as "an ideology which pits a virtuous and homogeneous people against a set of elites and dangerous 'others' who are together depicted as depriving (or attempting to deprive) the sovereign people of their rights, values, prosperity, identity and voice."

As slippery and shapeless as it may be, populism appeals to the average person rather than wealthy elites and at the centre of it all is a strong political figure driving the appeal. Albertazzi and McDonnell identify five key ideological elements that are manifest in populist political actors. These are: "emphasizing the sovereignty to the people, advocating for the people, attacking elites, ostracizing others, and invoking the heartland $(2008,3)$." They emphasise the difference between them and bureaucratic politicians' jargon which can be hardly understood by ordinary people. Mazzoleni (2003) provides examples of France's Jean-Marie Le Pen's singing in the parliament, and Italy's Umberto Bossi's use of both swearing (to express anger with status quo) and poetry in his speeches as all populist tactics of using emotional discourse to gain the support of the ordinary people. Another important attribute of populism is the presence of charismatic leader who is usually the pillar of the party. Populist parties generally organise themselves around a charismatic and highly controversial leader.

Populism is commonly linked to democracy or democratic processes. This relationship between populism and democracy has been examined by various scholars (De la Torre, 1997; Canovan, 1999, 2002; Mény and Surel 2002). Democracy, though defined by Powell (1982, p. 3) as "[t]he competitive electoral context, with several political parties organising the alternatives that face the voters, is the identifying property of the contemporary democratic process", is not synonymous to elections and neither is it only about elections. However, both populism and democracy have "firm and solid roots in the people" and "both indicate the paramount importance of the people", a compelling connection between democracy and populism can be made (Pasqutno 2008, p. 15). Additionally, several elements of populism are notable in most political ideologies adopted by different political parties. It is thus not surprising that populism is mostly visible during elections, a major constituent of democracy.

\section{Populism and the Media}

It is undoubted that the media play a very critical role in the life of all political systems. During elections, it becomes imperative that the media afford would-be voters all the information necessary for them to make informed choices about whom to elect or not. Thus, when discussing the functioning of democracy in any society, the media cannot be left out. Mazzoleni (2003) points out that the distinctive nature of the modern commercial 
media and their enormous capacity to affect the opinions and attitudes of mass audiences are key factors in the political arena. As a result, the media's contribution to the rise of populist groups in several national instances is a field that warrants investigation.

The terms 'populist media' or 'media populism', are used to refer to "highly commercialized media production and or news coverage that yield to general popular tastes, as in the case of tabloid media" (Mazzoleni 2008, p. 54). Elsewhere, Mazzoleni also points out that the media cannot simply ignore what is newsworthy and hence the presence of a news making populist individual increases the chances of coverage. He argues that newsworthy politicians are those defying the existing order, their abrasive language and emotive issues brandished by charisma. "The coverage of all this may amount to unintentional yet concrete support for populist actions" (Mazzoleni 2003 , p. 7). However, because populist sentiments and the politicians who promote them are irresistible newsmakers, one can argue that the populist media are a product of political populism. On the other hand, an argument that political populism is to a certain extent a product of intense media attention can also be made.

Studies show that populist politicians have a strong influence on the agenda of media (Kleinnijenhuis and Rietberg, 1995; McCombs and Reynolds, 2002). However, in certain cases the media may themselves put attention-catching issues on the agenda for political reasons. In the case of elections coverage, the media may deliberately want to influence the audience towards favouring a political party. In addition, and specifically relating to the media, populist leaders tend to utilise certain strategies to reign in the media and win its attention. These strategies are of course in addition to the populist leader's personality, which often works to attract the media on its own. According to Mazzoleni, Stewart, and Horsfield, (2003, p. 230, 232) the strategies used by populist leaders and movements include: playing the role of the underdog; the use of professional expertise; rallies; free media publicity; staging events; and tactical attacks on the media.

Also visible in media populism is what researchers have termed as the 'convergence of goals' that occurs between the media and populists (Mazzoleni, 2008, p. 59, 62). This happens because the two see a need for each other. Beata Ociepka makes a similar observation when she states that the "relationship between the media and populist politicians is reciprocal. Both sides in the relationship are conscious of possible manipulation, but at the same time are fated to cooperate" (2005, p. 223). The paper will endeavour to show how these issues have been expressed in Zambia using our sampled media.

When discussing populism and media, a conversation on mediation is also critical. Mediation is a term that has varied meanings and applications in various fields of study. For example, in media research, the concept has been used "to refer simply to the act of transmitting something through the media" or "the overall effect of media institutions existing in contemporary societies, the overall difference media make by being there in our social world" (Couldry, 2008, pp. 373-391). Mediation thus implies the possibility that the media can influence and shape representation and how audiences eventually construct the communication (Livingstone, 2009, p. 5). Mediation is therefore also important in how messages, in this case populist messages, are presented (Sorensen, 2018). Populists are able to harness this power of mediation in their relationship with the media and use it to further their populist stance on various matters in a country. This paper will show how the Patriotic Front party in Zambia, both under Michael Sata and Edgar Lungu have leveraged on this relationship using both mainstream and alternative media to communicate populist ideas.

\section{Social Media and Populism}

Social Media have become increasingly important to political communication and to media practice. Because of their ability to directly connect ordinary people to the politicians, populists have found social media to be a gift that keeps giving. Social media "provide the populists with the freedom to uncontestedly articulate their ideology and spread their messages" (Engesser et al. 2017, p. 1110). Though there have been several studies investigating political communication and social media, those that engage with social media and populism are especially rare in Africa. 
Populists have thrived on social media for many reasons. One of the main motivations is that social media are the sites where the people are. Social media usage is ever on the increase with platforms such as Facebook having billions of active users. It is not surprising therefore that those that claim to speak for the people will establish themselves where they know the people are and once there, they can obtain "direct, unmediated access to the people's grievances" (Kriesi 2014, p. 363). Using social media, populists can make linkages that would not be possible with legacy media, essentially bypassing the passive, controlled and gatekeeper-heavy 'old' using the more direct, active and peer-networked new media platforms (Klinger and Svensson, 2015, 1248; Canovan, 2002, p. 34). Apart from going against the terms of use for the respective platforms, social media offer populists free-range, allowing them to stir past editorial obligations and news values in traditional media, to venture into the sensational, controversial, unconventional and sometimes the less factual (see Klinger and Svensson, 2016; Engesser et al., 2017).

The examination of social media in this study is crucially important as it sheds light on how populism has divulged itself in the era of social media. This does not negate the importance of the analysis that relates to traditional media. Further, it does not suggest that populism has only been manifest on social media. Rather, it acknowledges that media populism has continued to thrive and has found a way to exist in a new form that is strengthened by social media. This analysis is also meant to paint a more complete picture of what Engesser et al. (2017, p. 1110) identifies as the "hybrid media system" within which contemporary media operate and social media plays an important part.

\section{Background: Sata and Zambia's populist turn}

Michael Chilufya Sata had been a long-standing politician and statesman who served in the presidencies of Kenneth Kaunda (Zambia's First and Second republic, 1964 to 1991) and Frederic T, J Chiluba (between 1991 and 2001, the Third Republic). His founding of the Patriotic Front was in response to President Chiluba's decision to appoint Levy Mwanawasa as his successor, overlooking Sata despite his loyal support for Chiluba's failed bid to secure an unconstitutional third term as president (Larmer and Fraser, 2007; Simutanyi, 2010; Mambwe, 2019). At the time, Sata was a senior cabinet member in Chiluba's Movement for Multiparty Democracy (MMD) government. The PF participated in the presidential elections in 2001 despite having been formed just months before the polls. Sata would only form government in 2011, after also losing to other elections, in 2006 and 2008.

Sata was a charismatic leader who gave moving speeches and spoke passionately and strongly on issues that affected and appealed to the average Zambian. He held controversial positions that appealed to his base. For example, he spoke strongly against Chinese investors and called them 'infesters', and openly pledged support to Taiwan, much to the aggrievement of Chinese diplomats in the country. By the end of the 2006 general elections, Sata's popularity and celebrity spread like wildfire giving him a significant foothold in several urban centres in the country. However, he was unable to unseat the incumbent Levy Patrick Mwanawasa of the MMD, handpicked by Chiluba as his successor after his unconstitutional third term bid was thwarted in 2001. That election cemented the PF's position as the main opposition party, with Sata as the country's president-in-waiting.

Larmer and Fraser $(2007$, p. 611, 622) have suggested that Sata's articulation of populist politics in that election cycle was an even more interesting outcome than the MMD's return to office. They further describe Sata as a leading exponent of populism whose skill was to consistently identify the popular mood of the day, to ally himself to his advantage, and to associate himself with mobilisations that demonstrate popular engagement with the issue. Sata can easily be described as a leader who as Betz and Immerfall (1998) put it, is endowed with distinctive public speaking skills, and in some cases with "media-genic" personal qualities, which they shrewdly exploit to gain popularity and media attention. 
Sata also typically employed highly emotional, slogan-based, tabloid-style language, combining verbal radicalism and symbolic politics with the tools of contemporary political marketing to disseminate his ideas among the electorate. These tactics by the PF created some form of a social movement consisting mostly of the "common people" (vendors in the streets and marketplaces, public transport drivers and the working class). These were the emergent PF party cardholders or carders who, according to Larmer and Fraser (2007) dominated Zambia's urban spaces during election campaigns. These were people who had felt politically isolated and alienated by society and elite politicians. The support from groups such as these, coupled with the party's populist rhetoric continued to the 2011 Elections.

\section{Integration of the media into the political system}

\section{(a) The case of the Post Newspaper, in relation to the 2011 Presidential Elections}

The Patriotic Front won the September 2011 presidential vote by 41.98 percent (against the ruling MMD's 35.42 percent) and gained control of parliament with 60 seats out of 150 seats, while the rest were shared among the other four parties (Electoral Commission of Zambia 2011). While the election results represented the people's loss of confidence in the MMD government, it is also not farfetched to argue that Sata's presidential bid this time was successful because of his articulation of populist politics and the media's buy-in into his populist themes.

In addition to the populist tendencies already highlighted, Sata appropriated popular music in his election bid. He adopted Wesley 'Dandy Crazy' Chibambo's song Donchi Kubeba as the official campaign song and slogan. The song was a popular anthem that was not only a popular feature at PF campaign rallies, but received a lot of media airplay, both paid for and for free. In the song Donchi Kubeba, the PF encouraged the electorate to receive and enjoy the 'free' campaign gifts from the ruling MMD but not to divulge who they would vote for. The term 'Donchi Kubeba' was thus used to mean 'don't tell them' (with 'donchi' being a colloquialisation of 'don't'). “The strategy was inventive: 'Take the gifts, enjoy the freebies, but don't tell them who you will vote for" (Mambwe 2019, p. 173). Sata's abrasive expression allowed for an angry and disenfranchised urban population to share this confrontational stand (Hamusokwe, 2014). The campaign was no longer a PF campaign, rather, it became the people's campaign, as ordinary citizens felt they could relate to the populist positions of the party and its leader. The song was a crowning jewel that galvanised masses. With all this and much more happening, it came as no surprise, for a variety of reasons, that the media jumped on the populist bandwagon. Following the Donchi Kubeba craze, musicians were ready to jump on the populist bandwagon and pen lyrics and record songs that would appeal to and entertain the masses. The expected monetary gain and widespread recognition were motivating enough for musicians. However, there is no evidence to suggest that many were successfully rewarded.

In highlighting the entangling of populism with the media in the 2011 elections, this study primarily analyses content from the privately-owned newspaper The Post. Founded in 1991, the Post was among the few prominent private media institutions in Zambia. The paper's co-founder and long-time managing editor was Fred M'membe. The paper became an important part of the newly liberalised media space. It is said to have had a dual management approach: running as a business on one hand but also taking a non-governmental or civil society organisation advocacy style in its approach to national issues (Banda, 2004, Hamusokwe, 2018). For the most part, the paper had been an independent voice in a media environment in which the state significantly controlled the nation's media apparatus. The paper's coverage of Sata and the PF would be a shift form its established modus operandi as an independent voice.

The study also examined the Zambia Daily Mail, a public newspaper. This examination was meant to provide a contrast to the main analysis of The Post. The Zambia Daily Mail, being state-owned, was pro-MMD and almost ignored the PF, whereas The Post was highly critical of the MMD and very favourable to the PF.

From the analysis, it was clear that while both newspapers had 100\% political coverage on their frontpage headlines in the period between September 1, 2011 to September 30, 2011, The Post had more pro-PF headlines and none were pro-MMD. The Zambia Daily Mail, on the other hand, had more pro-MMD headlines, most of which were also against other parties. However, it was also observed that immediately after the elections and 
inauguration of President Sata, the Zambia Daily Mail started carrying pro-PF headlines. The content and type of reporting in the two newspapers indicated a clear lack of objectivity and reflected the influence of media ownership on editorial independence.

Besides being critical of the ruling MMD, The Post developed a very close relationship with the then opposition leader Sata and his Patriotic Front. Headlines such as "PF is ready to Change Zambia for Good" (The Post, September 17, 2011) and "Sata to improve Defense Security Staff Conditions" (The Post, September 14, 2011), are examples of the depth of the alliance that was forged. This coalition signalled a convergence of political logic and media logic. It should be noted that compared with to the Zambia Daily Mail and public media in general, The Post had for many years enjoyed the trust and confidence of its readers. By persistently providing a critical perspective of the government of the day, The Post established itself as a credible source of information. It's alliance with a political party and later government sullied the paper's public support because it was now greatly compromised.

At the expense of professional journalism, a group of editors and reporters sublimated political logic and produced copy that pleased political candidates and appealed to the populist masses. It is not clear whether this was all for the sake of increasing revenue or obtaining political favours. This created an environment of 'newsroom populism' and journalists who failed to adapt had to be relieved of their duties. For instance, two reporters, Sydney Mungala and Collins Chali, were allegedly fired from The Post for not supporting the PF. The duo sued the paper for wrongful dismissal. ${ }^{1}$ Another group of eight journalists at the paper was understood to have already been fired for the same reason. The Post s 'marriage' with Sata and the PF deprived its free-thinking journalists of job security and protection as a result of editorial views that aligned with the populist views of Sata.

In this interpretation, The Post reflected and transmitted the populist sentiments espoused by the PF partly to serve its commercial interests by appealing to the masses. The paper neglected to keep an eye on the important issues, providing checks and balances by becoming a steppingstone for the PF party and its populist leader. The headlines were not short of populist theatrics such as the ones about the MMD spokesperson, Dora Siliya captured at different times in the campaign period. These include headlines such as: "My husband was lasy in bed... Dora explains her divorce" (The Post, September 10, 2011) and "Dora urges men to admire her bums" (The Post, September 11, 2011). The story leads were crafted to bring Siliya into disrepute. Both stories, covered at public campaign rallies that Siliya addressed, hardly reflected election-related pronouncements.

Further, the 'sweetheart contract' between the PF and The Post was evidenced by the newspaper's decision to have seemingly attached reporters and photographers to the campaign permanently. The newspaper also published photos showing massively attended PF political rallies, whereas photos of MMD rallies showed patches of children in attendance. In a sense, an argument that the paper became a key communication campaign strategy for the $\mathrm{PF}$ is all the more conceivable.

In the aftermath of the election, The Post continued its editorial support for the PF even after the party formed government. As a result of this union, many journalists from the paper, it seems, were rewarded with political appointments. For example, Amos Malupenga, who was the Managing Editor, was appointed to the position of Permanent Secretary in the Ministry of Information and Broadcasting and Tourism, and Joe Kaunda, his former deputy became the Deputy High Commissioner at the Zambian mission in South Africa. George Chellah, who wrote a significant number of the pro-PF stories (52\%) in the campaign period analysed, was appointed as President Sata's Special Assistant for Press and Public Relations. Chibaula Silwamba, who wrote 29 \% of the proPF stories, was appointed First Secretary for Press and Public Relations Permanent Mission at the United Nations, while Patson Chilemba, with 19\% of the stories, became Press Attaché at the Zambian High Commission in South Africa. Many others were appointed in other Zambian diplomatic missions in different countries. With several journalists and key staff from The Post and other pro-PF media organisations placed in strategic government positions, it was not surprising that several media institutions experienced a metamorphosis of sorts from being part of the fourth estate and watchdog of society to being the fourth organ of the government. On the 
other hand, the fate of many other journalists who did not join the Sata bandwagon, was different. This is particularly true for those from public media institutions who were allegedly labelled to be pro-MMD. Some were either fired or retired 'in national interest' and others transferred to man remote offices of the media institutions.

For a while, The Post continued to parrot the ruling PF and Sata. President Sata continued with his populist charisma and rhetoric in the media. This relationship did not last, however. The cracks were inevitable as allegiances changed.

\section{(b) Popular music, social media and new alliances in the press: The 2016 Presidential Elections}

The Patriotic Front government immediately set out to honour campaign promises. The UPND had become the main opposition party, with Hichilema still its president. Sata enjoyed a positive relationship with the media for the most part, perhaps still benefiting from the relationships forged in the 2011 campaign period. However, in 2014, Sata died in in office, hardly two years before the end of his first term. A by-election to elect a president who would complete the five-year term was scheduled for January 2015. However, the governing party found itself in an embarrassing power wrangle on who would take over as president of the party and candidate in the election. After months of debate and infighting, and a few resignations, the party elected Edgar Chagwa Lungu as its leader and candidate in the polls. PF won the by-elections with slender margin of 27,757 votes between Lungu and Hichilema. Even though the PF won, it was clear to both the party and the nation that Lungu was no Sata.

When the scheduled 2016 elections came, the PF retained President Lungu as its candidate. By this time, the party's relationship with The Post was viciously severed. The Post did not align itself with Lungu's PF and became very critical of his administration, often contrasting him to their 'darling' Sata (Bwalya 2017, p. 1555). The Lungu regime would later ensure the demise of the paper.

While the party did not have a populist charismatic figure as its leader, the PF reflected mastery of populist campaign tactics. The party enjoyed significant advantage of incumbency to strengthen their position in the elections. According to Gyimah-Boadi, incumbency is used by political rulers "to manipulate electoral institutions, electoral rules and procedures; to siphon off state resources and deploy them into partisan use in elections; to commission development projects; to extort donations from private business people and rent-seekers (2007, p. 29). In the case of the PF, incumbency gave the party access to public resources, unlimited coverage from the public media, and the ability to use development projects for its political mileage. Rather stealthily, covert clientelism was used, a practice in election campaigns where a party works hard to 'buy' votes in messages "wittingly wrapped in public goods of development" (Bwalya 2017, p. 1559). This became the foundation of the party's campaign, to highlight its achievements in the last five years, and use that as the selling point.

One may argue that the party judiciously and ingeniously crafted a slogan that would draw the focus from Edgar Lungu to what the party had achieved. This was a departure from previous elections where Sata was the focal point, or in the 2015 elections where the aim was to sell Edgar Lungu as 'a sure thing leader' (interpretation of the "ifintu ni Lungu" slogan used). In the new strategy, the thrust was to show what the party had done and to argue that no other party could achieve that. And thus, the "sonta epo wabomba" theme was born. Stated in full, the party and its supporters would say in the Bemba language: Sonta epo wabomba, nga wafilwa sela tubombeko" meaning "point at what you have done (show us your works), if you can't, move over, let us to work." Emphasis was placed on the party's public works and other achievements attained in the short period Lungu had been president. To further sell this idea, and in addition to their dominance and control over the public media, the party reverted to its winning formula of using popular music.

The use of popular music in political communication has continued to generate academic interest. For example, Gorzelany-Mostak observes that during elections, "electoral candidates employ a range of tactics to harness the sound, symbols and rhetoric of pop culture" (2017, p. 4). Nchindila (2008), Mambwe (2019) and Kalobwe (2021) have highlighted how popular music has been used in Zambian politics, especially during elections, primarily to sale the candidate, highlight the achievements, make promises, persuade voters, and even taunt opponents. 
Several songs titled "sonta epo wabomba" were recorded. Analysis of the lyrics show that the focus of the songs was to artistically highlight the successes of the PF and Lungu in his short time as head of state, and, to taunt the other presidential contenders who according to the songs had no achievements to show the people of Zambia. In one of the songs, the artist, Rich 'Rich Bizzy'Chilufya, highlights what Lungu had done (mostly projects started by Sata). He challenges other candidates to show what they had done. Part of the song says:

Uyu kateka wesu, alikula ifipatala [This our leader has built hospitals]

Akula amasukulu [He has built schools]

Akula nemisebo [He has built roads]

Nga webo finshi wacita [What about you, what have you done?]

(Mambwe, 2019, p. 176)

At the large campaign rallies, which are themselves a characteristic of populist politics (Mazzoleni, Stewart, and Horsfield, 2003), musical performances took up a significant portion of the time. These would see the various candidates or party officials take to the dance floor, much to the amusement of the crowds. Even Edgar Lungu was seen dancing on several occasions. Beyond the rallies, the PF took their songs to radio and paid for these songs to be played at commercial rates. The songs thus became regular features on local radio stations that were keen to cash in on the election money.

Other than popular music, the PF strategically took advantage of social media to propagate its populist messages. The party had already been actively using social media before the elections. This time, the party was perhaps even more focused. Social media emerged as important dynamic in the 2016 elections because of increased internet access in the country. This increase was influenced by the growth in access to smartphones and the reduction in prices of mobile internet. In a study examining digital media, urban spaces and the materiality of publics in the two elections in Zambia, Willems (2019, p. 5, 6) details the changes that took place between the two elections. While mobile internet accounted for the largest market for internet access as early as 2011 (Mambwe, 2015), only 2.8 percent of the population had access to mobile internet in 2011. At the time, mobile internet access was mostly via 3G USB Dongles (modems), 3G enabled phones, and at internet cafes. By 2016, mobile access had increased to 32.3 per cent. Therefore, according to Willems, a rise in social media use was the natural result of this increase. For example, Facebook usage grew exponentially from 117,520 users in 2011, to 1.4 million by 2016, its therefore became an important platform for politicians and political parties. Factors such as the reduced prices of smartphones, mostly influenced by the coming of cheaper Chinese brands such as those owned by Techno Mobile $^{3}$ (Techno, Infinix and iTel), and increased competition in the mobile sector leading to reduced prices of data, have contributed to increased social media use. Projects such as Facebook's Free Basics may also have contributed to this increase. ${ }^{4}$

Social media was used to share high-quality photos from the party's rallies. The aim of these photos was to show the large crowds in attendance as a demonstration of the party's popularity. Additionally, several photos of completed development projects were posted. These could include captioned photos of roads, schools and health centres. Additionally, the party shared highly strategic photos of Edgar Lungu that were meant to influence voters. There were: photos of Lungu speaking or dancing at rallies with cheering crowds to perhaps show his popularity and the popularity of his agenda; photos of Lungu interacting with ordinary Zambians such as marketers, school children and working class Zambians in natural settings, to perhaps show that Lungu stood for everyone and was a person that had time and heart for Zambians of any class; and photos of Lungu praying or reading the bible, to highlight his Christianity, an important factor in Zambian politics, and to further the idea that Lungu was Godordained. All these elements helped to strengthen the party's populist messages.

Beside photos, social media platforms were used to share campaign videos. Willems (2016) observes that the videos, which included drone footage of crowds, were also used to visually demonstrate the party's popularity. 
The videos were broadcast adverts that were also posted on social media (Facebook, YouTube and Twitter) and open to comments and sharing. One of the early videos titled "Join Millions of Fellow Zambians" 5 shows footage of the party's official campaign launch event held at Lusaka's Heroes Stadium. The video begins with various aerial shots of an almost empty stadium, followed by a montage of crowds arriving and entering the stadium as the stands fill up. In the background, one of the party campaign songs that suggests Edgar Lungu was the one that the people wanted plays. More drone shots follow, this time of a filled-up stadium. Edgar Lungu is shown arriving and is thronged by the crowds, and later shown addressing the people, and a diegetic dropout occurs as he utters the words "One Zambia!", and the crowds respond, "One Nation!". A similar video featuring the PF's launch event in the Copperbelt Province, a party stronghold, was produced.

Between Facebook and Twitter, usage of the latter was on the periphery. The number of Zambian's using Twitter has remained significantly lower than those of Facebook. Its use in the Zambian political space is fast growing and popular with activists and Zambians in the diaspora. As a result, Twitter has been popular with the main opposition party, the UPND, whose president, Hichilema has been active on the platform even before the elections. Hichilema joined the platform in October, 2012, contrasted to Lungu's official twitter account created on August 16, 2016, five days after the elections.

As for Facebook, two official pages were central to the party's strategy, Lungu's Page (Edgar Chagwa Lungu) and the party's own page (Patriotic Front - PF). On both pages, several updates were made in a day and each of these posts generated thousands of comments, likes and impressions. The comments from each post were a mixed bag of supporters and non-supporters, spammers and others who merely tagged other Facebook users. The PF also sponsored some posts to increase the audience reach of the messages. Besides the official Facebook pages, other PF or Edgar Lungu Pages were also very active. Pages such as Friends of the President - His Excellency Edgar Chagwa Lungu and various regional pages of the party were also active. However, many of these merely reposted or shared the posts from the official pages. A social media news organisation called Smart Eagles was also instrumental in propagating PF news and information on social media platforms. Launched in May 2016, Smart Eagles stated on its page that its vision was "to ignite passion and harness creative ideas that enlighten, educate, inform, entertain, inspire young people for a better Zambia." "Smart Eagles positioned itself as the de-facto official new (social) media outlet for the PF. The savvy page often carried stories from the PF camp before any (online or traditional) media outlet did and had a knack for branded exclusive high-quality photographs and artwork and highly pro-PF, anti-anybody else headlines. Smart Eagles would continue to operate with the same strategy years after the elections and acquiring over 500,000 Facebook likes by 2019.

To complement radio and television broadcasts, the PF used Facebook to stream its events such as its rallies and press briefings. This afforded more people to follow the events as they happened. Willems (2016) notes that the live streams "enabled voters to watch rallies at their workplace, on the go or at home in the evenings" as well as enabling the party to receive immediate reactions from voters.

Overall, the PF, in using both mainstream and alternative media, managed to buttress their self-declared populist characteristic as a pro-poor party by portraying their main political rival Hichilema of the UPND as an elitist with questionable morals because his wealth, and poor understanding of the realities of a life of poverty. Edgar Lungu on the other hand was the humble, praying, Bible-toting Christian man who had lived among the people in a very poor neighbourhood and was in touch with the people. These ideas were expressed in viral posts, song lyrics, photographs and promoted adverts.

\section{Discussion}

An outline of the evolution of the intermingling of populist politics with the media in Zambia's recent political history has been presented in this paper. Using the examples of the two very different election periods when the Patriotic Front had dissimilar candidates, the paper has drawn attention to some of the ways the intermingling of 
populism and the media continued to take root. The media are certainly important to the spread of populist agendas. As the media in postcolonial states such as Zambia continue to develop, populist politicians and parties also continue to find ways to harness the media's power. The various means of mass communication are without question essential for their messaging and success. The traditional media remain ever so important. In many African countries, where public media are often run by the governments in office, populist figures in opposition depend on independent media to spread their messages. Those in office will often utilise incumbency to benefit from the media channels within the state system, in addition to independent media that they may find to be favourable.

As seen in either scenario, media coverage, whether in positive or negative light is part of the populist's schema in their attempts to persuade audiences. This paper further shows that populism equally thrives with alternative media. The use of popular music and the internet are examples of this. Popular music, as Schoening and Kasper (2012) have argued, is used to make emotional appeals in political messaging because of its ability to persuade. The PF utilised the power of music to connect with the ordinary, to create and express emotions that can move masses, people, and to carry messages that resonate with people. The party understood that it can sell its ideas, its candidates and itself as a party in an artistic and non-elitist manner, thus appealing to the non-elite masses. In addition, social media, as has been shown, became increasingly important for the spread of populist ideas. Facebook proved to be a platform of choice for the party, as it able to reach and engage hundreds of thousands of voters on a platform that was already popular with the people.

Populists, populist organisations and populist media influence the political process in ways that pose challenges to democracy. During the elections, coverage is widely skewed and forthrightly unobjective. Dangerous dichotomous political coverage, "us vs them" is created despite the actual political playing field being more diverse and less contentious. As shown, this de the public opportunities to thoroughly scrutinise all the competing political players presenting themselves for election. Ultimately, some of the arguments and counter arguments from the politicians outside the top two brackets are not likely to see the light of day in the media. Most often than not, articles, whether in The Post in 2011 or on aligned social media platforms in 2016, were one-sided presentations of the events without a chance of getting the other side of the story or a counter argument. This killed any meaningful democratic and pluralistic debate in its truest sense and affected voting patterns according to the dictates of the media.

\section{Conclusion}

The question of whether populist media - a product of political populism - is good for democracy remains a contentious issue. The intermingling of populists or populist movements with the media leads to significant bias in the media against competitors during elections. This affects decision-making for the voters that rely on the media's representation of the candidates. Voters who do not have access to well-balanced media content featuring competing candidates' views are denied the ability to make well-informed choices. When the media 'merge' with populist thinking, whether loosely or permanently, they are instead driven by political logic. This logic then dictates and influences media logic, thereby injuring the media's claim for balance and fairness.

\section{Disclosure statement}

No potential conflict of interest was reported by the authors.

\section{Notes}

1. Sydney Mungala and Collins Chali's case was heard in the Industrial Relation's Court but the case was dismissed on December $6^{\text {th }}$ 2012. Later appeals were also unsuccessful. $\underline{\text { https://zambialii.org/node } / 7563}$

2. Another song with the same title was recorded by Chester (Moses Ngandwe) and Mampi Mukape. 
3. Owned by Transsion, Techno enjoys the largest market share in Africa, ahead of other International manufacturers (https://edition.cnn.com/2018/10/10/tech/tecno-phones-africa/index.html)

4. Free Basics is a Facebook project meant to provide free internet access on selected sites. Read more on: https://info.internet.org/en/story/free-basics-from-internet-org/

5. Available here: https://www.youtube.com/watch?v=n1K6eWnIumg

6. Eagles Facebook page: https://www.facebook.com/pg/SmartEaglesZambia/about/?ref=page internal

\section{References}

Albertazzi D., McDonnell D. (2008) Introduction: The Sceptre and the Spectre. In D. Albertazzi \& D. McDonnell (Eds.), Twenty-First Century Populism: The Spectre of Western European Democracy (pp. 1-11). London: Palgrave Macmillan. DOI: https://doi.org/10.1057/9780230592100_1

Betz, H. G., \& Immerfall, S. (Eds.). (1998). The new politics of the right: Neo-populist parties and movements in established democracies. London: Palgrave Macmillan

Bwalya, J. (2017). Unravelling clientelism in the Zambian electoral campaigns. Third World Quarterly, 38(7), 1551-1565. DOI: https://doi.org/10.1080/01436597.2016.1229568.

Canovan, M. (1999). Trust the people! Populism and the two faces of democracy. Political studies, 47(1), 2-16. DOI: https://doi.org/10.1111/1467-9248.00184

Canovan, M. (2002). Taking politics to the people: Populism as the ideology of democracy. In Y. Meny \& Y. Surel, Democracies and the populist challenge (pp. 25-44). London: Palgrave Macmillan.

DOI: $\underline{\text { https://doi.org/10.1057/9781403920072 } 2 .}$.

Cheeseman, N., Ford, R., \& Simutanyi, N. (2014). Is there a 'populist threat' in Zambia.? In C.Adam, P Collier, \& M. Gondwe (Eds.), Zambia: Building Prosperity from Resource Wealth, (pp. 339-365).

DOI: https://doi.org/10.1093/acprof:oso/9780199660605.003.0014.

Couldry, N. (2008). Mediatization or mediation? Alternative understandings of the emergent space of digital storytelling. New media \& society, 10(3), 373-391. DOI: https://doi.org/10.1177/1461444808089414.

De la Torre, C. (1997). Populism and democracy: political discourses and cultures in contemporary Ecuador. Latin American Perspectives, 24(3), 12-24. DOI: http://www.jstor.org/stable/10.2307/2634095.

Electoral Commission of Zambia (2011). 2011 Elections Report. URL (last checked 5 August 2019) https://www.elections.org.zm/2011elections.php

Engesser, S., Ernst, N., Esser, F., \& Büchel, F. (2017). Populism and social media: How politicians spread a fragmented ideology. Information, communication \& society, 20(8), 1109-1126.

DOI: https://doi.org/10.1080/1369118X.2016.1207697

Gorzelany-Mostak, D. (2017). Hearing girls, girls, girls on the 2016 campaign trail. Journal of Popular Music Studies, 29(3), e12235. DOI: https://doi.org/10.1111/ipms.12235

Gyimah-Boadi, E. (2007). Political parties, elections and patronage: Random thoughts on neo-patrimonialism and African democratization. In M. Basedau, G. Erdmann \& A. Mehler (Eds.), Votes, Money and Violence: Political Parties and Elections in Sub-Saharan Africa (pp. 21-33). Uppsala, Sweden: Nordiska Afrikainstitutet.

Hamusokwe, B. (2014). Media populism: a challenge to democracy? A case of the 2011 elections in Zambia. Paper presented at the annual meeting for the International Association of Media and Communication Researcher (IAMCR), Hyderabad, July 15-19.

Hamusokwe, B. N. (2018). Theoretical perspectives: Towards a Zambian political economy of communication. Communicatio, 44(2), 1-19. DOI: https://doi.org/10.1080/02500167.2018.1493522

Kalobwe, L. C. (2021). The Patriotic Front's Use Popular Music in the 2016 Elections in Zambia: A Literature Review. Review International Journal of Research Publication and Reviews (IJRPR), 2(8), 339-344. Available at DOI: http://dx.doi.org/10.2139/ssrn.3835097

Kleinnijenhuis, J., \& Rietberg, E. M. (1995). Parties, media, the public and the economy: Patterns of societal agenda-setting. European journal of political research, 28(1), 95-118. DOI: https://doi.org/10.1111/j.1475-6765.1995.tb00488.x

Klinger, U., \& Svensson, J. (2015). The emergence of network media logic in political communication: A theoretical approach. New media \& society, 17(8), 1241-1257. DOI: https://doi.org/10.1177/1461444814522952.

Kriesi, H. (2014). The populist challenge. West European Politics, 37(2), 361-378.

DOI: https://doi.org/10.1080/01402382.2014.887879.

Laclau, E. (1977). Towards a theory of populism. Politics and ideology in Marxist theory, 143-98. 
Larmer, M., \& Fraser, A. (2007). Of cabbages and King Cobra: populist politics and Zambia's 2006 election. African Affairs, 106(425), 611-637.

DOI: https://doi.org/10.1093/afraf/adm058

Laycock, D. (1990). Populism and Democratic Thought in the Canadian Prairies, 1910-1945. Toronto: University of Toronto Press.

Livingstone, S. (2009). On the mediation of everything: ICA presidential address 2008. Journal of communication, 59(1), 1-18. DOI: https://doi.org/10.1111/j.1460-2466.2008.01401.x

Mambwe, E. (2015). The state of internet technology in Zambia (a media perspective). In Media Industry in Zambia: A Handbook. UNZA DMCS/Mission Press. Permalink/DOI: https://ssrn.com/abstract=3547958

Mambwe, E. (2019). The Discursive Role of Music in African Elections: A Perspective from Zambia. In Music and Messaging in the African Political Arena (pp. 166-184). IGI Global. DOI: https://doi.org/10.4018/978-1-5225-7295$\underline{4 . \operatorname{ch} 009}$

Mazzoleni, G., Stewart, J., \& Horsfield, B. (Eds.). (2003). The Media and Neo-Populism: A Contemporary Comparative Analysis. Westport, CT: Praeger Publishers.

Mazzoleni, G. (2008). Populism and the Media. In D. Albertazzi \& D. McDonnell (Eds.), Twenty-First Century Populism: The Spectre of Western European Democracy, (pp. 49-64). Basingstoke, Hampshire: Palgrave Macmillan.

Mény, Y, \& Surel, Y. (2002). Democracies and the populist challenge. London: Palgrave Macmillan.

McCombs, M, \& Reynolds, A. (2002). News Influence on Our Pictures of the World. In J Bryant \& D. Zillmann (Eds.), Media Effects: Advances in Theory and Research, 2nd Edition (pp. 1-18). Mahwah, New Jersey: Lawrence Erlbaum Associates.

Nchindila, B. M. (2008). Honest by chance: An investigation into Bemba music in Zambian politics. Muriki, 5(2), 298-322. DOI: https://doi.org/10.1080/18125980902798581

Ociepka, B. (Ed.). (2005). Populism and media democracy (No. 2726). Wdawn. Uniwersytetu Wrocawskiego. Wroclaw University Press

Pasquino, G. (2008). Populism and democracy. In Twenty-First Century Populism, (pp. 15-29). London: Palgrave Macmillan. DOI: https://doi.org/10.1057/97802305921002

Powell, G. B. (1982). Contemporary Democracies: Participation, Stability, and Violence. Cambridge, MA: Harvard University Press.

Schoening, B S., \& Kesper, E. T. (2011). Don't stop thinking about the music: The politics of songs and musicians in presidential campaigns. Lexington Books.

Simutanyi, N. (2010). The 2008 presidential elections in Zambia: incumbency, political contestation and failure of political opposition." In IESE/CMI Conference on Election Processes, Liberation Movements and Democratic Change in Africa, Maputo, pp. 9-11. URL (last checked 15 July 2019)

http://www.iese.ac.mz/lib/publication/proelit/Neo Simutanyi.pdf

Sorensen, L. (2018). Populist communication in the new media environment: a cross-regional comparative perspective. Palgrave Communications, 4(1), 48. DOI https://doi.org/10.1057/s41599-018-0101-0.

Willems, W. (2016). Facebook Live-Streaming, Drones and Swag Selfies: Youth Culture and Visual Social Media in \#ZambiaDecides. Africa at LSE Blog. URL (last checked 5 August 2019)

http://blogs.lse.ac.uk/africaatlse/2016/08/31/facebook-live-streaming-drones-and-swag-selfies-youth-culture-and-visualsocial-media-in-zambiadecides $/$.

Willems, W. (2019). 'The Politics of Things': Digital Media, Urban Space and the Materiality of Publics. Media, Culture and Society, February. SAGE Publications L. DOI: https://doi.org/10.1177/0163443719831594 